American Journal of Environmental Sciences 6 (3): 286-294, 2010

ISSN 1553-345X

(C) 2010 Science Publications

\title{
Differential Gene Expression in Zebrafish (Danio rerio) Following Exposure to Gaseous Diffusion Plant Effluent and Effluent Receiving Stream Water
}

\author{
Ben F. Brammell and Andrew J. Wigginton \\ Department of Civil Engineering, University of Kentucky, \\ Lexington, KY 40506, USA
}

\begin{abstract}
Problem statement: The expression of six genes known to serve as bioindicators of environmental stress were examined using real-time quantitative PCR in liver tissue extracted from zebrafish (Danio rerio, Hamilton) exposed to effluent and effluent containing stream water associated with the Paducah Gaseous Diffusion Plant (PGDP). Approach: The PGDP, the only active uranium enrichment facility in the US, is located in western Kentucky and discharges treated effluents into several surrounding streams. Environmentally relevant concentrations of several heavy metals and polychlorinated biphenyls (PCBs) can be found in effluents emerging from the plant as well as in receiving streams. Fish were exposed in the laboratory to water from both effluents and downstream areas as well as to water from an upstream reference site. Expression of six genes known to be altered by metal and/or PCB exposure was quantified at both 7 and 14 day time points. Results: Transcription of the biomarker enzyme cytochrome P4501A1 (CYP1A1) was significantly elevated in fish exposed to one plant effluent at both the 7 (16 fold) and 14 (10 fold) day time points. Sediment PCB levels from this site were the highest observed in the study, indicating PCBs may be contributing to the elevated CYP1A1 mRNA. Additionally, catalase, an enzyme responsible for hydrogen peroxide detoxification and known to be impacted by metal contamination, demonstrated significant alterations in expression in the effluent containing the highest concentrations of most metals observed in this study. Interestingly, despite the presence of metal levels consistent with the induction of metallothionein in other studies, no metallothionein induction was observed. All other stress biomarker encoding genes were likewise unaffected by effluent water exposure. Conclusion/Recommendations: These results indicate that contaminant levels observed in this system altered transcription of catalase and CYP1A1 but failed to significantly alter metallothionein, superoxide dismutase, or glutathione peroxidase, providing important data linking pollutant levels and physiological effects.
\end{abstract}

Key words: Zebrafish, gene expression, metals, ethoxyresorufin-o-deethylase

\section{INTRODUCTION}

Traditional environmental monitoring approaches typically devote much effort to quantifying contaminant levels while lending significantly less effort to understanding the biological impact of those contaminants. Many contaminants are known to affect organisms through both acute lethal toxicity and via more subtle physiological effects leading to long term adverse consequences and sometimes even alterations in population gene structure (Elskus et al., 1999; Nacci et al., 1999). In the latter case, organisms in an environment appear superficially unaltered but in actuality have undergone changes that may lead to a myriad of detrimental consequences. This study examines the impact of contaminant containing waste water at the transcriptional level by examining six genes known to be altered in the presence of contamination by heavy metals or organic toxicants. This study is significant as it offers insight into subtle physiological alterations that serve as indicators of the biological impacts effluents exert on organisms in the surrounding environment.

The use of biomarkers allows researchers to effectively evaluate the biological response to pollutants of aquatic and terrestrial organisms (Buchneli and Fent, 1995), in many cases enabling detection of otherwise imperceptible impact. Biomarkers are measurements in body cells or tissues that indicate biochemical or cellular modifications in response to the presence of a toxicant (National Research Council, 1987). Unlike contaminant concentrations in tissues or

Corresponding Author: Ben F. Brammell, Department of Civil Engineering, University of Kentucky, Lexington, KY 40506, USA 
sediments, which provide no information on biological effect, alterations in biomarkers indicate that chemicals present in the system are biologically active. Biomarkers can serve as early warning signs, reflecting initial impacts of pollutants in ecosystems long before mortality, reproductive inhibition, or other effects are observed (Buchneli and Fent, 1995).

Biomarkers may be specific indicators of pollutant classes or general indicators of response to physiological alterations such as oxidative stress. The xenobiotic metabolizing enzyme cytochrome P4501A1 (CYP1A1) is a phase I biotransformation enzyme widely used as a biomarker of exposure to planar organic compounds such as Halogenated Aromatic Hydrocarbons (HAHs) and Polynuclear Aromatic Hydrocarbons (PAHs) (Elskus and Stegeman, 1989; Whyte et al., 2000). While endogenous levels of the enzyme are relatively low, strong and rapid (within hours) induction of CYP1A1 mRNA and catalytically active protein occurs in fish exposed to inducing compounds (Stegeman and Hahn, 1994), making CYP1A1 an ideal biomarker of exposure to such pollutants. In addition to CYP1A, phase II xenobiotic metabolizing enzymes such as Glutathione STransferase (GST) are also inducible by organic pollutants and used as biomarkers of exposure (Lemaire et al., 1996; Armknecht et al., 1998). Metallothioneins (MTs) are small intracellular proteins with a high degree of affinity for both endogenous and xenobiotic metal cations and as such play an important role in detoxification of several environmentally relevant metals and provide protection from free radicals (Andrews, 2000; Kagi and Schaffer, 1988; Klaassen et al., 1999). Exposure to metal ions is known to induce MT transcription (Rhee et al., 2009; Waalkes and Goering, 1990) making those useful biomarkers of metal contamination (Guohui et al., 2009; Monserrat et al., 2007).

One of the well established impacts of metal contaminants on organisms is the increased generation of Reactive Oxygen Species (ROS); products produced naturally during metabolism that experience enhanced production following heavy metal exposure. Under normal conditions the ROS produced during metabolism are prevented from causing toxic effects by antioxidants such as reduced Glutathione (GSH), vitamins and several enzymes. These enzymes are found in a number of species including a wide range of teleosts (Ferraris et al., 2002; Ritola et al., 2002). Superoxide Dismutase (SOD), Catalase (CAT) and Glutathione Peroxidase (GPX) are some of the most important antioxidant enzymes. SOD transforms superoxide to hydrogen peroxide and divalent oxygen.
Catalase is the major enzyme responsible for hydrogen peroxide detoxification, converting hydrogen peroxide to water and oxygen, thereby protecting the organism from oxidative damage (Woo et al., 2009). Numerous studies report elevated hepatic CAT activity in response to aqueous metal exposure (Atli et al., 2006; Gravato et al., 2006). CAT detoxifies hydrogen peroxide by catalyzing its breakdown into water and divalent oxygen. GPX also breaks down hydrogen peroxide. As previously mentioned, one hallmark of metal contamination is the increased production of ROS, often accompanied by a concomitant increase of these enzymes, facilitating their use as biomarkers.

The objective of this study was to assess the physiological impact of PGDP effluent on organisms residing in the surrounding environment by examining the expression of genes known to be altered by both organic and metal contaminants. The streams surrounding the PGDP that are the focus of this study have a long and well documented history of contamination by both metals and PCBs (Birge et al., 2000; Price, 2007). These streams contain populations of fish typical to this region of the country and although bioaccumulation of contaminants in these fish is well documented, few studies have examined alteration in physiology that occurs as a consequence to this accumulation. The expression of six genes was quantified in fish exposed to an upstream reference area, effluent water, or sites downstream of plant effluents. Alterations in gene expression of these enzymes in impacted but not reference areas would be a strong indicator that contamination was altering normal fish physiology. This study quantifies biological effects on organisms residing in and below plant effluents thereby providing insight into the impact of these effluents on resident organisms.

\section{MATERIALS AND METHODS}

Fish: Zebrafish (Danio rerio) were obtained from a commercial vendor and held in the lab for one week prior to the onset of the experiment. All zebrafish were acclimated in reference site water (Site BC1) and housed in $4 \mathrm{~L}$ glass containers with twenty fish per container. Two containers were utilized for each site, each housing twenty fish. Fish were held at $24^{\circ} \mathrm{C}$, a $14 \mathrm{~h}$ light: $10 \mathrm{~h}$ dark light cycle provided vigorous aeration and fed Tetramin flake food ad libitum twice daily. Only sexually immature or male fish were utilized in this experiment to prevent alterations in hormone levels associated with spawning female fish from skewing experimental results. 
Experimental protocol: Fish were exposed to either reference water $(\mathrm{BC} 1)$ or water from one of two effluents or two downstream stream sites $(\mathrm{BC} 2$ and BC3). Water was collected from the stream sites 24-36 $\mathrm{h}$ prior to the initiation of the experiment and transported to the laboratory. Water was acclimated to the appropriate temperature and the experiment begun on day 0 . Complete water changes were conducted on days $3,6,9$ and 12 of the experiment in all containers utilizing water collected prior to day 0 and stored in the lab. On experimental day 7 , ten animals were removed from each container and placed on ice for $5 \mathrm{~min}$ in $100 \mathrm{~mL}$ of the water in which they were being held, weighed and then sacrificed via pithing. Complete viscera was removed and immediately preserved by immersion in RNA Later®. Livers were then held on ice for approximately 3 $\mathrm{h}$ until transferred to storage at $-80^{\circ} \mathrm{C}$. On experimental day 14 , the ten remaining animals were removed from each container, anesthetized, weighed and sacrificed via pithing. Water samples were taken for metal analysis at the time of water collection and from the containers holding fish on day 14 .

Water quality analysis: On-site water quality measurements, which included temperature, $\mathrm{pH}$, dissolved oxygen and conductivity, were taken with a YSI 650 MDS meter with a YSI 600 QS multiparameter sonde. Hardness was calculated from $\mathrm{Ca}$ and $\mathrm{Mg}$ concentrations measured in water via Inductively Coupled Plasma Optical Emission Spectroscopy (ICPOES) according to procedures described by American Public Health Association Method 2340B (Clescerl et al., 1991).

Metal analysis: Water samples, from both field and laboratory collections, were collected in $50 \mathrm{~mL}$ Corning graduated plastic centrifuge tubes and acidified to $0.5 \%$ with trace metal grade nitric acid. Samples were directly measured for Total Recoverable metal (TR) on a Varian Vista MPX simultaneous ICP-OES using methods derived from the US EPA (2008). Mixed metal certified standards were used to make all standard curves and check standards. Sample value was corrected for deviation from check standard concentrations.

PCB analysis: Sediment and floodplain samples were collected from the upper $5-10 \mathrm{~cm}$ of sediment in acetone rinsed glass jars and placed on ice until refrigerated in the laboratory. Wet sediment extractions of PCBs were performed following US EPA SW-846 Method 3540C (EPA, 2008). Reported values are corrected for deviation from check standards analyzed after approximately every 10 samples during analysis.
Fillets from fish were analyzed for PCBs after removal of scales but with the skin left on. Samples were analyzed for Aroclors 1248, 1254 and 1260 using EPA standard method SW-846 Method 8082 (polychlorinated biphenyls by gas chromatography (EPA, 2008) on a Hewlett-Packard (HP) Model 5890A gas chromatograph equipped with an electron capture detector. Certified standards for all three listed Aroclors were used for both standard curves and check standards. Reported values are corrected for deviation from check standards analyzed after approximately every 10 samples during analysis.

Total RNA extraction and reverse transcription: Viscera was removed from $-80^{\circ} \mathrm{C}$ and thawed on ice at which time the liver was separated from the rest of the viscera and transferred to Ambion's lysis buffer. Total RNA was isolated from hepatic tissue using Ambion's RNAqueous@-Micro Kit according to the manufacturer's instructions. To assure elimination of genomic DNA contamination, Ambion's RNAqueous ${ }^{\circledR}$ -Micro DNase I treatment was applied to the total RNA solution. RNA concentration and quality was assessed using a Thermo Scientific Nanodrop 2000. All 260/280 readings were greater than 1.9 indicating minimal protein contamination. First strand cDNA was generated using Applied Biosystem's High Capacity RNA-to-cDNA Kit according to the manufacturer's instructions. Reverse transcriptase controls that included all components except the template RNA were included with each RT reaction.

Real-time PCR: Quantification of mRNA in the livers was conducted by real-time PCR using the iQ SYBR Green Supermix (Bio-Rad Laboratories, Inc., Tokyo, Japan) and iCycler iQTM real-time PCR detection system (Bio-Rad Laboratories, Inc.,). The primers for CYP1A, MT, SOD and Beta Actin were used as previously reported (Lister et al., 2009; Chan et al., 2006; Malek et al., 2004; Jonsson et al., 2007) and those for GST, GPX and CAT were designed using Primer-Blast. If possible, primers were designed to span an intron/exon junction to avoid amplification of genomic DNA. If that was not possible primers were designed to include an intron to facilitate the recognition of genomic DNA amplification. Sequences of all primers utilized are listed in Table 1.

Each $25 \mu \mathrm{L}$ reaction mixture contained $1 \mu \mathrm{L}$ of each primer, $12.5 \mu \mathrm{L}$ of $2 \times$ iQ SYBR Green Supermix, $1 \mu \mathrm{L}$ template DNA and $9.5 \mu \mathrm{L}$ nuclease free water. Reaction mixtures were denatured for $2.5 \mathrm{~min}$ at $95^{\circ} \mathrm{C}$, followed by 40 cycles of $15 \mathrm{sec}$ at $95^{\circ} \mathrm{C}$ and $1 \mathrm{~min}$ at $60^{\circ} \mathrm{C}$. After PCR, the specificity of the product was assured by analyzing the melt curve to distinguish target amplification from non-specific products. 
Am. J. Environ. Sci., 6 (3): 286-294, 2010

Table 1: Primers utilized for reverse transcription polymerase chain reactions to amplify the target genes

\begin{tabular}{llll}
\hline Gene & Forward primer & Reverse primer & Prod. size \\
\hline CYP1A1 & 5'-CTGGACGAAAACTCCAACCTG & 5'-GATAGTGTCGAAACCGGCTCC & 87 \\
Superoxide dismutase 2 & 5'-CGCATGTTCCCAGACATCTA & 5'-GAGCGGAAGATTGAGGATTG & 100 \\
Metallothionein 2 & 5'-GCC AAG ACT GGA ACT TGC AAC & 5'-CGC AGC CAG AGG CAC ACT & 124 \\
Beta actin 1 & 5'-CAACAGAGAGAAGATGACACAGATCA & 5'-GTCACACCATCACCAGAGTCCATCAC & 138 \\
Glutathione peroxidase 4b b & 5'-GGACGATCCAAGCGTGGTGGA & 5'-CAGCCGTCACACGTCTGGGC & 148 \\
Catalase & 5'-AGTGCTCCTGACGTCCAGCCA & 5'-TGAAGAACGTGCGCACCTGGG & 115 \\
Glutathione S-transferase & 5'-GCTGCAGGAGCTGTTTCCCTCC & 5'-GAGGTGGCTCAACACGGCCT & 172 \\
\hline
\end{tabular}

A single melt curve was observed for all primer sets. In all cases, mRNA levels were normalized to the expression of beta actin mRNA. Real time PCR of all samples was conducted in duplicate.

Fold induction values were calculated using the delta/delta method (Livak and Schmittgen, 2001). Homogeneity of variances was evaluated by Levene's test (1960) before parametric tests were performed (Levene, 1960). If necessary, data were logtransformed. Data were analyzed using one-way Analysis Of Variance (ANOVA); differences among means were tested using Tukey's post hoc test (Day and Quinn, 1989; Sokal and Rohlf, 1994). Two containers were utilized for each site and differences between means among containers from the same sites were first tested. When all these comparisons were found to be similar, data from each container were pooled for final analysis.

\section{RESULTS}

Expression of CYP1A mRNA was significantly elevated in zebrafish exposed to water from Effluent 2 at both the 7 (16 fold) and 14 (10 fold) day time points (Fig. 2 and 3). The fish exposed to water from the stream site located directly downstream of Effluent 2 (BC3) had CYP1A levels that appeared somewhat elevated at these same time points, although in both cases these levels were not significantly different from the upstream reference site BC1 (Fig. 1-3). In contrast, expression of CYP1A mRNA in zebra fish exposed to water from Effluent 1 and the site just downstream, $\mathrm{BC} 2$, was similar to expression observed in reference fish (Fig. 2 and 3). The only other significant alterations in gene expression were observed in CAT expression at the 14 day time point (Fig. 3) where CAT expression was significantly depressed in fish exposed to both stream site BC2 and Effluent 2 relative to Effluent 1 (Fig. 3). Expression of all other genes was statistically similar.

Limnochemical data for water all stream sites are shown in Table 2. Temperature, $\mathrm{pH}$ and $\mathrm{DO}$ were relatively similar across all sites while hardness and conductivity were somewhat higher in sites downstream of effluents.

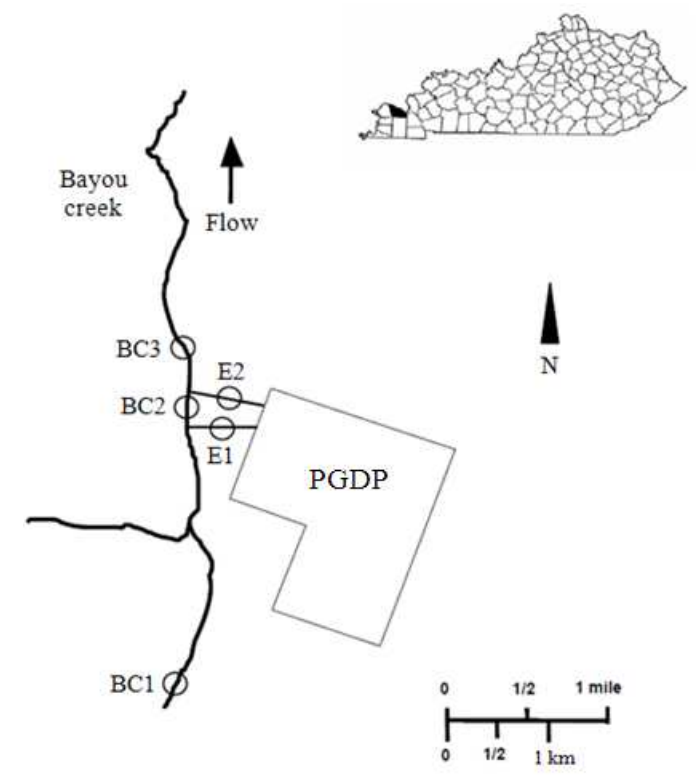

Fig. 1: Location of study sites surrounding the Paducah Gaseous Diffusion Plant in McCracken County, Kentucky

Metal water concentrations taken before and after the laboratory exposures are displayed in Table 3 and 4. Copper was elevated 5.6 fold and zinc 2.5 fold in Effluent 1 relative to the upstream reference site (BC1) in pre-exposure water. Likewise magnesium and sodium were elevated 9.8 and 7.5 fold respectively in Effluent 1 pre-exposure water relative to $\mathrm{BC} 1$. Zinc in $\mathrm{BC} 1$ displayed higher levels in post versus preexposure water.

PCB levels are shown for stream sediment (Table 5), flood plain soil (Table 6) and fish (Table 7). The only sediment PCB levels above detection limits were found in Effluent 2 and stream site BC3 (Table 5). These same sites also possessed flood plain PCB levels over detection limits although other sites such as BC2 and Effluent 1 also had flood plain PCB levels over detection limits (Table 6). Fish PCB levels were more sporadic with each site, including the upstream reference site, exhibiting some fish with PCB levels over the detection limits (Table 7). 
Am. J. Environ. Sci., 6 (3): 286-294, 2010
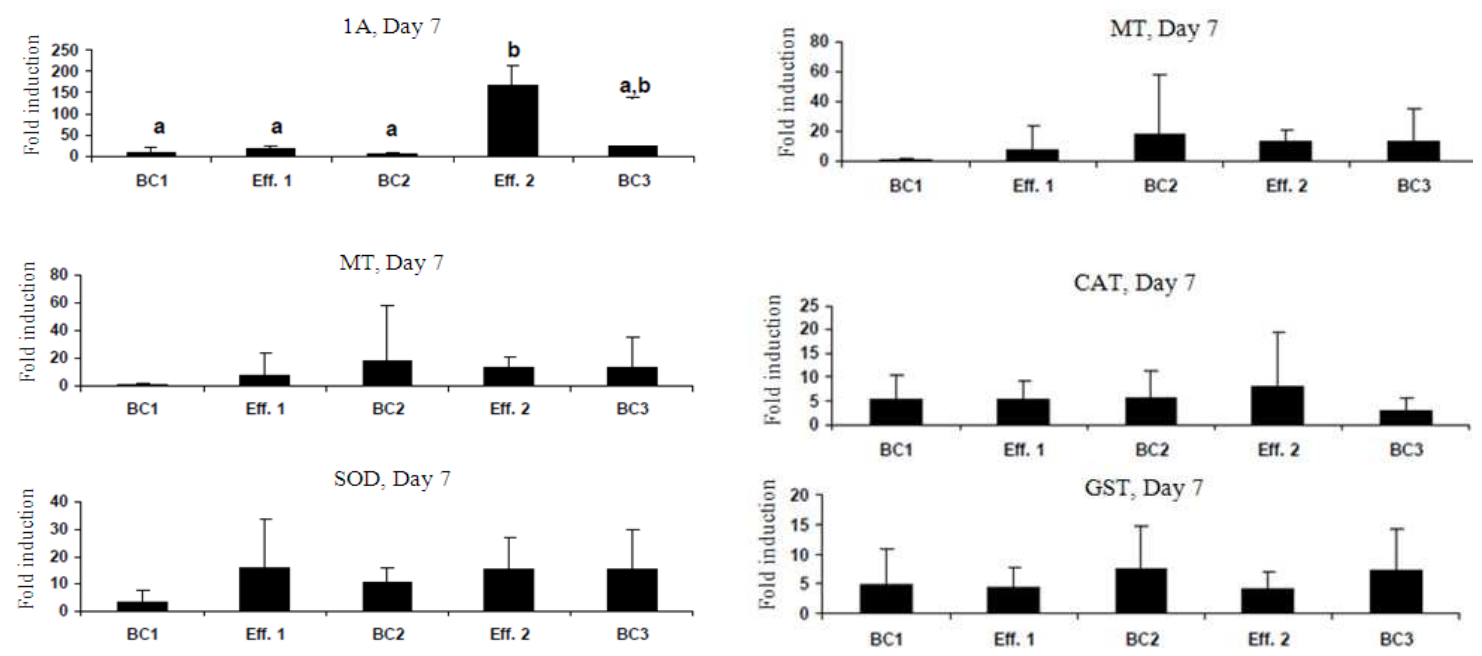

Fig. 2: Relative expression of cytochrome P4501A (1A), Superoxide Dismutase (SOD), Glutathione Peroxidase (GPX), Metallothionein (MT), Catalase (CAT) and Glutathione S-Transferase (GST) in zebrafish following a seven day exposure to effluent and effluent containing stream water

1A, Day 14
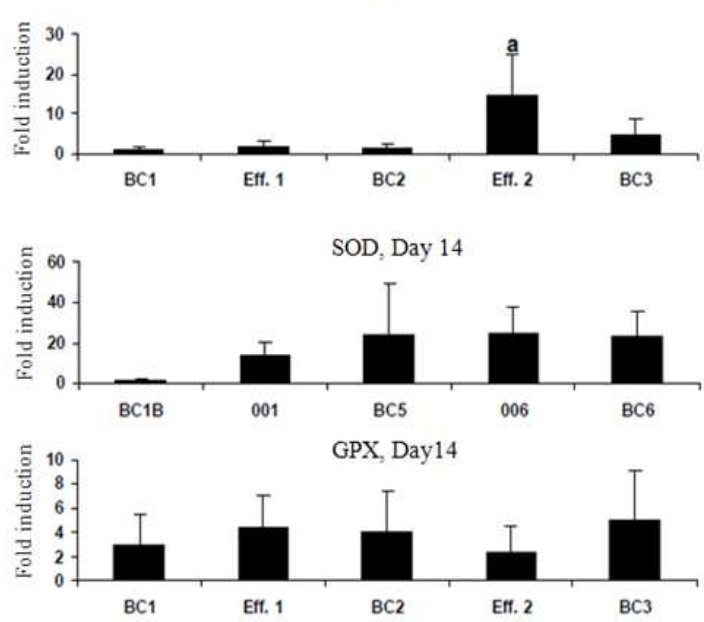
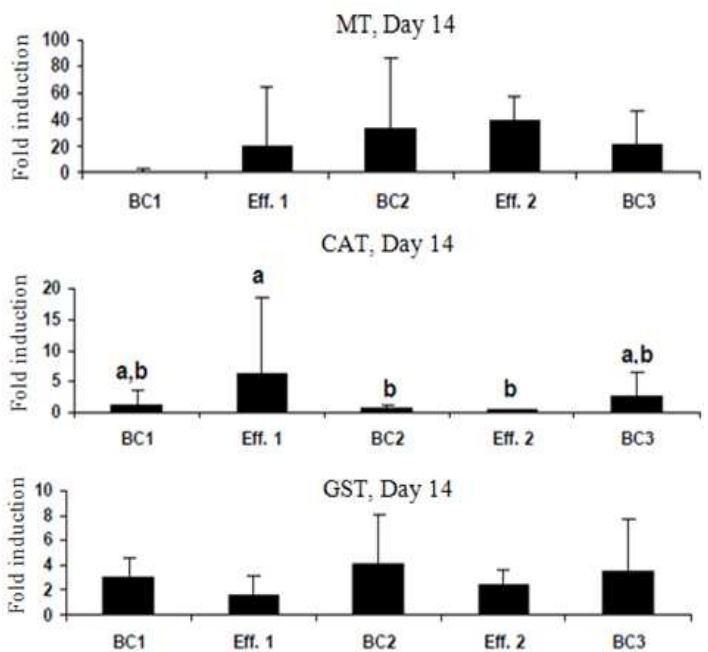

Fig. 3: Relative expression of cytochrome P4501A (1A), Superoxide Dismutase (SOD), Glutathione Peroxidase (GPX), Metallothionein (MT), Catalase (CAT) and Glutathione S-Transferase (GST) in zebrafish following a fourteen day exposure to effluent and effluent containing stream water

Table 2: Water quality results for stream water samples from the Bayou Creek system collected May 11-13, 2009

\begin{tabular}{lllll}
\hline Station & Temperature $\left({ }^{\circ} \mathrm{C}\right)$ & $\mathrm{pH}$ & $\begin{array}{l}\text { Conductivity } \\
\left.(\mu \mathrm{S} \mathrm{cm})^{-1}\right)\end{array}$ & $\begin{array}{l}\text { Dissolved } \\
\text { oxygen }\left(\mathrm{mg} \mathrm{O}_{2} \mathrm{~L}^{-1}\right)\end{array}$ \\
\hline BC1 & 20.9 & 7.19 & 158 & 8.34 \\
Effluent 1 & na & na & na & na \\
BC2 & 24.8 & 7.51 & 240 & 8.82 \\
BC3 & 21.8 & 7.47 & 654 & 8.42 \\
\hline
\end{tabular}

Table 3: Metal water concentrations $\left(\mu \mathrm{g} \mathrm{L}^{-1}\right)$ in pre-exposure water collected from Bayou Creek and used for zebrafish exposure study, May 2009

\begin{tabular}{lllllrrrrr}
\hline Station & $\mathrm{Al}$ & $\mathrm{Cr}$ & $\mathrm{Cu}$ & $\mathrm{Fe}$ & $\mathrm{Mg}$ & $\mathrm{Na}$ & $\mathrm{Ni}$ & $\mathrm{Pb}$ \\
\hline BC1 & 308.0 & $<0.500$ & 0.808 & 712.1 & 3231 & 16196 & 5.010 & $<1.0$ & 1.633 \\
BC2 & 123.0 & $<0.500$ & 0.934 & 348.6 & 4969 & 21477 & 2.999 & $<1.0$ & 1.688 \\
Effluent 1 & 456.9 & 0.893 & 4.490 & 569.7 & 31837 & 120749 & 5.896 & $<1.0$ \\
BC3 & 209.1 & 0.618 & 1.505 & 378.9 & 14078 & 5.073 \\
\hline
\end{tabular}


Am. J. Environ. Sci., 6 (3): 286-294, 2010

Table 4: Metal water concentrations $\left(\mu \mathrm{g} \mathrm{L}^{-1}\right)$ in post exposure water collected from Bayou Creek and used for zebrafish exposure study, May

\begin{tabular}{lrllllrrrr}
\hline Station & \multicolumn{1}{c}{$\mathrm{Al}$} & $\mathrm{Cr}$ & $\mathrm{Cu}$ & $\mathrm{Fe}$ & $\mathrm{Mg}$ & $\mathrm{Na}$ & $\mathrm{Ni}$ & $\mathrm{Pb}$ & $\mathrm{Zn}$ \\
\hline BC1 & 51.58 & 0.525 & $<0.500$ & 169.10 & 3813 & 8579 & 1.260 & $<5.00$ & 4.890 \\
Effluent1 & 197.80 & 0.836 & $<0.500$ & 376.20 & 7977 & 15551 & 0.959 & $<5.00$ & 14.550 \\
BC2 & 55.96 & 0.627 & $<0.500$ & 97.56 & 6006 & 15724 & 1.146 & $<5.00$ & 8.489 \\
Effluent 2 & 39.95 & 0.743 & 1.478 & 54.68 & 39681 & 140763 & 6.932 & $<5.00$ & 5.596 \\
BC3 & 62.28 & 0.660 & $<0.500$ & 99.55 & 16232 & 53308 & 3.628 & $<5.00$ & 6.607 \\
\hline
\end{tabular}

Table 5: PCB concentrations in sediment from Bayou Creek collected April 2009

\begin{tabular}{|c|c|c|c|c|c|}
\hline \multirow[b]{2}{*}{ Station } & \multirow[b]{2}{*}{ Sample $^{1}$} & \multicolumn{3}{|c|}{ Aroclor Conc. $\left(\mu \mathrm{g} \mathrm{Kg}^{-1}\right)$} & \multirow[b]{2}{*}{ Total } \\
\hline & & 1248 & 1254 & 1260 & \\
\hline$\overline{\mathrm{BC} 1}$ & 1 & $<5.007$ & $<5.007$ & $<5.007$ & $<5.007$ \\
\hline $\mathrm{BC} 1$ & 2 & $<5.179$ & $<5.179$ & $<5.179$ & $<5.179$ \\
\hline Effluent 1 & 1 & $<6.901$ & $<6.901$ & $<6.901$ & $<6.901$ \\
\hline Effluent 1 & 2 & $<6.961$ & $<6.961$ & $<6.961$ & $<6.961$ \\
\hline $\mathrm{BC} 2$ & 1 & $<4.332$ & $<4.332$ & $<4.332$ & $<4.332$ \\
\hline $\mathrm{BC} 2$ & 2 & $<4.329$ & $<4.329$ & $<4.329$ & $<4.329$ \\
\hline Effluent 2 & 1 & 6.193 & 8.998 & $<6.807$ & 15.190 \\
\hline Effluent 2 & 2 & $<6.487$ & $<6.487$ & $<6.487$ & $<6.487$ \\
\hline $\mathrm{BC} 3$ & 1 & 7.230 & $<4.191$ & $<4.191$ & 7.230 \\
\hline $\mathrm{BC} 3$ & 2 & $<5.047$ & $<5.047$ & $<5.047$ & $<5.047$ \\
\hline
\end{tabular}

Bold letters indicate the presence of detectable PCBs: ${ }^{1}:$ Sample 1 and 2 are two separately analyzed samples from a single collected composite

Table 6: PCB concentrations in flood plain from Bayou Creek collected April 2009

\begin{tabular}{|c|c|c|c|c|c|c|}
\hline \multirow[b]{2}{*}{ Station } & \multirow[b]{2}{*}{ Sample $^{1}$} & \multirow[b]{2}{*}{ Dry weight (g) } & \multicolumn{3}{|c|}{ Aroclor Conc. $\left(\mu \mathrm{g} \mathrm{Kg}^{-1}\right)$} & \multirow[b]{2}{*}{ Total } \\
\hline & & & 1248 & 1254 & 1260 & \\
\hline$\overline{\mathrm{BC} 1}$ & 1 & 34.260 & $<5.838$ & $<5.838$ & $<5.838$ & $<5.838$ \\
\hline $\mathrm{BC} 1$ & 2 & 35.480 & $<5.637$ & $<5.637$ & $<5.637$ & $<5.637$ \\
\hline Effluent1 & 1 & 36.330 & $<5.505$ & $<5.505$ & $<5.505$ & $<5.505$ \\
\hline Effluent1 & 2 & 32.900 & $<6.079$ & $<6.079$ & 10.089 & 10.089 \\
\hline $\mathrm{BC} 2$ & 1 & 38.850 & $<5.148$ & $<5.148$ & $<5.148$ & $<5.148$ \\
\hline $\mathrm{BC} 2$ & 2 & 38.210 & $<5.234$ & 13.020 & 22.770 & 35.780 \\
\hline Effluent 2 & 1 & 32.577 & $<6.139$ & $<6.139$ & $<6.139$ & $<6.139$ \\
\hline Effluent 2 & 2 & 32.914 & $<6.076$ & $<6.076$ & 8.073 & 8.073 \\
\hline $\mathrm{BC} 3$ & 1 & 35.640 & $<5.612$ & $<5.612$ & $<5.612$ & $<5.612$ \\
\hline $\mathrm{BC} 3$ & 2 & 35.940 & $<5.565$ & 6.664 & 7.627 & 14.290 \\
\hline
\end{tabular}

Bold letters indicate the presence of detectable PCBs: ${ }^{1}$ : FP1 and FP2 are independent samples taken near the stream and approximately 5-10 m from the stream, respectively

Table 7: PCB concentrations in fish from Bayou Creek collected April of 2009

\begin{tabular}{|c|c|c|c|c|c|c|c|c|}
\hline \multirow[b]{2}{*}{ Station } & \multirow[b]{2}{*}{ Species } & \multirow[b]{2}{*}{ Length (mm) } & \multirow[b]{2}{*}{ Wt. (g) } & \multirow[b]{2}{*}{ Age (years) } & \multicolumn{3}{|c|}{ Aroclor Conc. $\left(\mu \mathrm{g} \mathrm{g}^{-1}\right)$} & \multirow[b]{2}{*}{ Total } \\
\hline & & & & & 1248 & 1254 & 1260 & \\
\hline $\mathrm{BC} 1$ & GS & 96 & 17.0 & 2 & $<0.077$ & $<0.077$ & $<0.077$ & $<0.0770$ \\
\hline $\mathrm{BC} 1$ & LS & 95 & 17.4 & 2 & $<0.071$ & $<0.071$ & $<0.071$ & $<0.0710$ \\
\hline $\mathrm{BC} 1$ & LS & 75 & 8.1 & 1 & $<0.179$ & $<0.179$ & $<0.179$ & $<0.1790$ \\
\hline $\mathrm{BC} 1$ & LS & 78 & 9.8 & 1 & 0.255 & $<0.174$ & $<0.174$ & 0.2550 \\
\hline BC1 & LS & 77 & 9.8 & 1 & $<0.157$ & $<0.157$ & $<0.157$ & $<0.1570$ \\
\hline $\mathrm{BC} 1$ & YBH & 150 & 48.4 & - & $<0.048$ & $<0.048$ & $<0.048$ & $<0.0480$ \\
\hline $\mathrm{BC} 2$ & BG & 115 & 30.6 & 2 & $<0.050$ & $<0.050$ & $<0.050$ & $<0.0500$ \\
\hline BC2 & Carp & 153 & 61.9 & 1 & 0.080 & 0.058 & $<0.027$ & 0.1380 \\
\hline BC2 & LS/GS & 116 & 30.7 & 2 & $<0.049$ & $<0.049$ & $<0.049$ & $<0.0490$ \\
\hline $\mathrm{BC} 2$ & LS & 147 & 71.3 & 3 & $<0.044$ & $<0.044$ & $<0.044$ & $<0.0440$ \\
\hline $\mathrm{BC} 2$ & LS & 139 & 65.4 & 2 & 0.068 & 0.045 & $<0.050$ & 0.1130 \\
\hline $\mathrm{BC} 2$ & LS & 120 & 41.4 & 2 & $<0.034$ & $<0.034$ & $<0.034$ & $<0.0342$ \\
\hline BC3 & BG & 73 & 6.6 & $<1$ & $<0.196$ & $<0.196$ & $<0.196$ & $<0.1960$ \\
\hline BC3 & GS & 79 & 7.9 & $<1$ & $<0.173$ & $<0.173$ & $<0.173$ & $<0.1730$ \\
\hline BC3 & LS & 96 & 16.5 & 1 & $<0.078$ & 0.129 & $<0.078$ & 0.1290 \\
\hline BC3 & LS & 85 & 17.1 & 1 & $<0.089$ & 0.090 & $<0.089$ & 0.0900 \\
\hline BC3 & BG & 53 & 3.7 & $<1$ & $<0.381$ & $<0.381$ & $<0.381$ & $<0.3810$ \\
\hline BC3 & YBH & 98 & 10.7 & - & $<0.175$ & $<0.175$ & $<0.175$ & $<0.1750$ \\
\hline BC3 & YBH & 170 & 59.6 & - & $<0.025$ & $<0.025$ & $<0.025$ & $<0.0250$ \\
\hline
\end{tabular}

Bold lettering indicates the presence of detectable PCBs 


\section{DISCUSSION}

The results of this study illustrate the utility of biomarker studies in pollutant monitoring as tools capable of indicating the presence of pollutants and allowing links to be drawn between pollutant levels and biological effects. Expression of CYP1A1 varied significantly between fish exposed to either upstream reference water or water from a downstream effluent. These alterations appear somewhat correlated with quantified PCB levels but may also due to an unidentified pollutant. Catalase mRNA expression differed among sites and was elevated relative to other sites in Effluent 1, the site containing the highest metal water concentrations. Furthermore, the genes altered in the study, CYP1A1 and CAT, are indicators of organic pollutants and oxidative stress, respectively, providing insight into the nature of contaminants present.

The strongly induced CYP1A mRNA in fish exposed to Effluent 2 water (16 fold over the reference site) appears to indicate the presence of an inducing compound in Effluent 2 water. Although unfortunately PCB water measurements were not available for any sites in this study, circumstantial measurements, such sediment, flood plain and fish, do indicate the presence of PCBs at this site, albeit at low levels. The most relevant indicator is likely sediment PCB concentrations which were above detectable limits only in Effluent 2 and stream site BC3. Although modest in terms of absolute concentration, other studies do report elevated CYP1A activity following exposure to systems containing lower sediment PCB levels (Kuzyk et al., 2005), making PCBs a likely candidate for the inducing compound. Certainly the possibility of other inducing compounds in the effluent, such as PAHs, cannot be eliminated.

It appears plausible that the elevated CAT levels in fish exposed to Effluent 1 water are related to the elevated metal concentrations found in this effluent. Effluent 1 had the highest readings of all metals in pre experiment water measurements and the highest readings of $\mathrm{Al}, \mathrm{Cr}, \mathrm{Fe}$ and $\mathrm{Zn}$ in post experiment water measurements. Previous studies have reported elevated CAT following exposure to levels of both $\mathrm{Cu}$ and $\mathrm{Zn}$ lower than those observed in this study (Woo et al., 2009).

Lack of significant alteration in other genes in this project is somewhat surprising given the metal concentrations present in water from Effluent 1. A recent study exposing Japanese medaka (Oryzias javanicus) to individual metals in the lab reported significant induction of GPX at $1 \mathrm{ppb}$ copper (Woo et al., 2009), approximately 5 times lower than the highest copper values observed in this study. In another study, goldfish exposed to $5.0 \mathrm{ppb} \mathrm{Cu}$, similar to the highest $\mathrm{Cu}$ value observed in this study, displayed GST activity elevated approximately 2.5 fold over controls while 5.0 $\mathrm{ppb} \mathrm{Cu}$ significantly suppressed GPX activity (approximately 0.6 fold) yet had no effect on SOD or CAT activity (Liu et al., 2006). Significant induction of MT mRNA in Kryptolebias marmoratus (mangrove killifish) has been reported following separate inlaboratory exposure to both $\mathrm{Cu}$ and $\mathrm{Zn}$ at $1 \mathrm{ppb}$, well below the values observed in our study (Rhee $e t$ al., 2009). While the metal levels in this experiment are relatively low, studies with other fish species do report alterations in protein or mRNA levels at contaminant levels similar to or below the highest levels observed in this study. The three studies mentioned above all used laboratory reconstituted water spiked with toxicants of interest while our study used water collected from an industrial environment. It is likely that metals in water from our study were less bioavailable than in the other studies with fewer free ions and more metals bound to particulates or existing as unavailable chemical species.

Metal concentrations were varied among individual metals and across sites. Several metals were either below detection limits at all sites $(\mathrm{Pb})$ or relatively homogenous across all sites ( $\mathrm{Fe}, \mathrm{Ni}$ and $\mathrm{Zn}) . \mathrm{Mg}$ and $\mathrm{Na}$ are included not as metals of primary interest to toxicology but as indicators of effluent contribution to downstream water chemistry. After receiving water from the effluents, stream water from site $\mathrm{BC} 3$ contained magnesium and sodium levels that were elevated 4.4 and 3.3 fold over $\mathrm{BC} 1$ water respectively. Perhaps the metals of most interest were $\mathrm{Al}$ and $\mathrm{Cu}$ which in pre-exposure water were elevated 1.5 and 5.6 fold respectively in Effluent 1 water over levels found in upstream reference $(\mathrm{BC} 1)$ water. Al levels remained elevated relative to controls in Effluent 1 post exposure water (3.6) while $\mathrm{Cu}$ levels dropped to below detection limits at all sites except Effluent 2.

\section{CONCLUSION}

This study illustrates the sensitivity and utility of PCR based biomarker studies and provides an important link between observed pollutant concentrations and biological effects. The alterations in CYP1A1 gene expression observed in this study appears linked to quantified contaminants although the possibility of an unknown organic inducer cannot be eliminated. While contaminant monitoring methods are well established and reliable, they provide no information on the effects of the contaminants in the environment. In addition, contaminant monitoring is 
relatively expensive limiting the number of contaminants that may be quantified. Biomarker studies of key genes provide a relatively inexpensive broad sweep method of detecting the presence of classes of inducers, allowing specific quantitative tests to then be implemented. This study presents novel data linking organism responses to environmental contaminants in a well characterized system, providing a crucial reference for future studies assessing the effects of pollutants on biota.

\section{ACKNOWLEDGEMENT}

This work was funded by the Kentucky Division of Waste Management within the Kentucky Energy and Environment Cabinet from a grant provided by the US Department of Energy.

\section{REFERENCES}

Andrews, G.K., 2000. Regulation of metallothionein gene expression by oxidative stress and metal ions. Biochem. Pharmacol., 59: 95-104. DOI: 10.1016/S0006-2952(99)00301-9

Armknecht, S.L., S.L. Kaattari and P.A. Van Veld, 1998. An elevated glutathione S-transferase in creosote-resistant mummichog (Fundulus heteroclitus). Aquat. Toxicol., 41: 1-16. DOI: 10.1016/S0166445X(97)00074-X

Atli, G., O. Alptekin, S. Tukel and M. Canli, 2006. Response of catalase activity to $\mathrm{Ag}{ }^{+}, \mathrm{Cd}^{2+}, \mathrm{Cr}^{6+}$, $\mathrm{Cu}^{2+}$ and $\mathrm{Zn}^{2+}$ in five tissues of freshwater fish Oreochromis niloticus. Comp. Biochem. Physiol., 143: 218-224. DOI: 10.1016/j.cbpc.2006.02.003

Birge, W.J., J.R. Shaw, J.A. Spromberg, A.J. Wigginton and C. Hogstrand, 2000. Metal body burden and biological sensors as ecological indicators. Environ. Toxicol. Chem., 19: 1199-1212. DOI: 10.1002/etc.5620190454

Buchneli, T. and K. Fent, 1995. Induction of cytochrome $\mathrm{P} 450$ as a biomarker for environmental contamination in aquatic ecosystems. Crit. Rev. Environ. Sci. Technol., 25: 201-268, DOI: 10.1080/10643389509388479.

Chan, K.M., L.L. Ku, P.C.Y. Chan and W.K. Cheuk, 2006. Metallothionein gene expression in zebrafish embryo-larvae and ZFL cell-line exposed to heavy metal ions. Mar. Environ. Res., 62: S83-S87. DOI: 10.1016/j.marenvres.2006.04.012

Clescerl, L.S., A.E. Greenberg and A.D. Eaton, 1991. Standard Methods for the Examination of Water and Wastewater. 20th Edn., American Public Health Association, USA., ISBN: 10: 0875532357, pp: 1325.
Day, R.W. and G.P. Quinn, 1989. Comparisons of treatments after an analysis of variance in ecology. Ecol. Monogr., 59: 433-463. DOI: $10.2307 / 1943075$

EPA, 2008. Test methods for evaluating solid wastes. US Environmental Protection Agency.

Elskus, A.A. and J.J. Stegeman, 1989. Induced cytochrome P-450 in Fundulus heteroclitus associated with environmental contamination by polychlorinated biphenyls and polynuclear aromatic hydrocarbons. Mar. Environ. Res., 27: 31-50. DOI: 10.1016/0141-1136(89)90017-2

Elskus, A.A., E. Monosson, A.E. McElroy, J.J. Stegeman and D.S. Woltering, 1999. Altered CYP1A expression in Fundulus heteroclitus adults and larvae: A sign of pollutant resistance? Aquat. Toxicol., 45: 99-113. DOI: 10.1016/S0166445X(98)00102-7

Ferraris, M., S. Radice P. Catalani, M. Francolini and L. Marabini et al., 2002. Early oxidative damage in primary cultured trout hepatocytes: A time course study. Aquat. Toxicol., 59: 283-296. DOI: 10.1016/S0166-445X(02)00007-3

Gravato, C., M. Teles, M. Oliveira and M.A. Santos, 2006. Oxidative stress, liver biotransformation and genotoxic effects induced by copper in Anguilla anguilla $\mathrm{L}$. the influence of pre-exposure to $\mathrm{b}$ naphthoflavone. Ecotoxicol. Environ. Safe., 65: 1821-1830. DOI: 10.1016/j.chemosphere.2006.04.005

Guohui, W., K.C. Wai and C.K. Ming, 2009. Differential regulation of zebrafish metallothionein-II (zMT-II) gene transcription in ZFL and SJD cell lines by metal ions. Aquat. Toxicol., 91: 33-43. DOI: 10.1016/j.aquatox.2008.10.004

Jonsson, M.E., R. Orrego, R. Woodin, J.V. Goldstone, and J.J. Stegeman, 2007. Basal and 3,3',4,4',5pentachlorobiphenyl-induced expression of cytochrome $\mathrm{P} 450$ 1A, $1 \mathrm{~B}$ and $1 \mathrm{C}$ genes in zebrafish. Toxicol. Applied Pharm., 221: 29-41. PMID: 17445853

Kagi, J.H. and A. Schaffer, 1988. Biochemistry of metallothionein. Biochemistry, 27: 8509-8515. DOI: $10.1021 / \mathrm{bi00423a001}$

Klaassen, C.D., J. Liu and S. Choudhuri, 1999. Metallothionein: An intracellular protein to protect against cadmium toxicity. Annu. Rev. Pharmacol. Toxicol., 39: 267-294. DOI: 10.1146/annurev.pharmtox.39.1.267

Kuzyk, Z.A., P.V. Hodson, S.M. Solomon and K.J. Reimer, 2005. Biological responses to PCB exposure in shorthorn sculpin from Saglek Bay, Labrad. Sci. Total Environ., 351-352: 285-300. DOI: 10.1016/j.scitotenv.2004.06.029 
Lemaire, P., L. Forlin and D.R. Livingstone, 1996. Responses of hepatic biotransformation and antioxidant enzymes to CYP1A-inducers (3methylcholanthrene, beta-naphthoflavone) in sea bass (Dicentrarchus labrax), dab (Limanda limanda) and rainbow trout (Oncorhynchus mykiss). Aquat. Toxicol., 36: 141-160, DOI: 10.1016/S0166-445X(96)00819-3

Levene, H., 1960. Robust Tests for Equality of Variances. In: Contributions to Probability and Statistics: Essays in Honor of Harold Hotelling, Olkin, I. (Ed.). Stanford, Stanford University Press, CA., pp: 278-292.

Liu, H., W. Wang, J. Zhang and X. Wang, 2006. Effects of copper and its ethylenediaminetetraacetate complex on the antioxidant defenses of the goldfish, Carassius auratus. Ecotoxicol. Environ. Safe., 65: 350-354. DOI: 10.1016/j.ecoenv.2005.09.002

Livak, K. and T. Schmittgen, 2001. Analysis of relative gene expression data using real-time quantitative PCR and the 2(-Delta Delta C(T)) method. Methods, 25: 402-408. DOI: 10.1006/meth.2001.1262

Lister, A., C. Reagan, J. Van Zwol and G.D. Kraak, 2009. Inhibition of egg production in zebrafish by fluoxetine and municipal effluents: A mechanistic evaluation. Aquat. Toxicol., 95: 320-329. DOI: 10.1016/j.aquatox.2009.04.011

Malek, R.L., H. Sajadi, J. Abraham, M.A. Grundy and G.S. Gerhard, 2004. The effects of temperature reduction on gene expression and oxidative stress in skeletal muscle from adult zebrafish, Comp. Biochem. Physiol., 138: 363-373. DOI: 10.1016/j.cca.2004.08.014

Monserrat, J.M., P.E. Martínez, L.A. Geracitano, L.L. Amado and C.M. Martins, 2007. Pollution biomarkers in estuarine animals: Critical review and new perspectives. Comp. Biochem. Physiol., 146: 221-234. DOI: 10.1016/j.cbpc.2006.08.012

Nacci, D., L. Coiro, D. Champlin, S. Jayaraman and R. McKinney et al., 1999. Adaptations of wild populations of the estuarine fish Fundulus heteroclitus to persistent environmental contaminants. Mar. Biol., 134: 9-17. DOI: $10.1007 / \mathrm{s} 002270050520$

National Research Council, 1987. Biological markers in environmental health research. Environ. Health Perspect., 74: 3-9. http://www.jstor.org/stable/3430428
Price, D.J., 2007. Use of In situ fish populations for biomonitoring polychlorinated biphenyl and metal pollution in moderately impacted freshwater streams. Ph.D. Thesis, University of Kentucky. http://hdl.handle.net/10225/716

Rhee, J.S., S. Raisuddin, D.S. Hwang, K.W. Lee and I.C. Kim et al., 2009. Differential expression of Metallothionein (MT) gene by trace metals and endocrine-disrupting chemicals in the hermaphroditic mangrove killifish, Kryptolebias marmoratus Ecotoxicol. Environ., Safe., 72: 206-212. DOI: 10.1016/j.ecoenv.2008.06.001

Ritola, O., D.R. Livingstone, L.D. Peters and P. Lindstrom-Seppa, 2002. Antioxidant processes are affected in juvenile rainbow trout (Oncorhynchus mykiss) exposed to ozone and oxygen supersaturated water. Aquaculture, 210: 1-19. DOI: 10.1016/S0044-8486(01)00823-7

Sokal, R.R. and F.J. Rohlf, 1994. Biometry. 4th Edn., W.H. Freeman and Company, New York, ISBN: 10: 0716786044 , pp: 88.

Stegeman, J. and M. Hahn, 1994. Biochemistry and Molecular Biology of Monooxygenases: Current Perspectives on Forms, Functions and Regulation of Cytochrome $\mathrm{P} 450$ in Aquatic Species. In: Aquatic Toxicology: Molecular, Biochemical and Cellular Perspectives, Malins, D.C. and G.K. Ostrander (Eds.). Lewis, Ann Arbor, ISBN: 10: 0873715454, pp: 87-206.

Waalkes, M.P. and P.L. Goering, 1990. Metallothionein and other cadmium-binding proteins: Recent developments. Chem. Res. Toxicol., 3: 281-288. DOI: $10.1021 / \mathrm{tx} 00016 \mathrm{a} 001$

Whyte, J.J., R.E. Jung, C.J. Schmitt and D.E. Tillitt, 2000. EthoxyresoRufin-O-Deethylase (EROD) activity in fish as a biomarker of chemical exposure. Crit. Rev. Toxicol., 30: 347-570. PMID: 10955715

Woo, S., S. Yuma, H.S. Park, T.K. Lee and J.C. Ryu, 2009. Effects of heavy metals on antioxidants and stress-responsive gene expression in Javanese medaka (Oryzias javanicus). Comp. Physiol. Biochem., 149: 289-299. DOI: 10.1016/j.cbpc.2008.08.002 